\title{
Neuromuscular Blockade with Rocuronium Bromide Increases the Tolerance of Acute Normovolemic Anemia in Anesthetized Pigs
}
A. Pape ${ }^{a}$
H. Kertscho ${ }^{a}$ P. Stein ${ }^{a}$
M. Lossen ${ }^{a}$
O. Horn ${ }^{a}$
S. Kutschker ${ }^{\mathrm{a}}$
B. Zwissler ${ }^{\mathrm{C}}$
O. Habler ${ }^{\text {b }}$

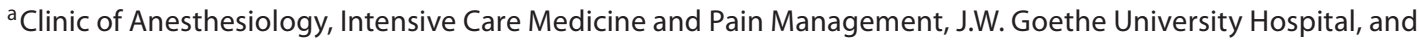

${ }^{b}$ Clinic of Anesthesiology, Surgical Intensive Care Medicine and Pain Management, Krankenhaus Nordwest, Frankfurt a.M., and 'Clinic of Anesthesiology, Ludwig Maximilian's University Hospital, Munich, Germany

\section{Key Words}

Neuromuscular blockade $\cdot$ Rocuronium bromide $\cdot$

Anemia tolerance $\cdot$ Pig

\begin{abstract}
Background: The patient's individual anemia tolerance is pivotal when blood transfusions become necessary, but are not feasible for some reason. To date, the effects of neuromuscular blockade (NMB) on anemia tolerance have not been investigated. Methods: 14 anesthetized and mechanically ventilated pigs were randomly assigned to the Roc group $(3.78 \mathrm{mg} / \mathrm{kg}$ rocuronium bromide followed by continuous infusion of $1 \mathrm{mg} / \mathrm{kg} / \mathrm{min}, \mathrm{n}=7$ ) or to the Sal group (administration of the corresponding volume of normal saline, $n=7$ ). Subsequently, acute normovolemic anemia was induced by simultaneous exchange of whole blood for a $6 \%$ hydroxyethyl starch solution (130/0.4) until a sudden decrease of total body $\mathrm{O}_{2}$ consumption $\left(\mathrm{VO}_{2}\right)$ indicated a critical limitation of $\mathrm{O}_{2}$ transport capacity. The $\mathrm{Hb}$ concentration quantified at this time point $\left(\mathrm{Hb}_{\text {crit }}\right)$ was the primary endpoint of the protocol. Secondary endpoints were parameters of hemodynamics, $\mathrm{O}_{2}$ transport and tissue oxygenation. $\boldsymbol{R e}$ sults: $\mathrm{Hb}_{\text {crit }}$ was significantly lower in the Roc group (2.4 \pm 0.5 vs. $3.2 \pm 0.7 \mathrm{~g} / \mathrm{dl}$ ) reflecting increased anemia tolerance.
\end{abstract}

NMB with rocuronium bromide reduced skeletal muscular $\mathrm{VO}_{2}$ and total body $\mathrm{O}_{2}$ extraction rate. As the cardiac index increased simultaneously, total body $\mathrm{VO}_{2}$ only decreased marginally in the Roc group (change of $\mathrm{VO}_{2}$ relative to baseline $-1.7 \pm 0.8$ vs. $3.2 \pm 1.9 \%$ in the Sal group, $p<0.05$ ). Conclusion: Deep NMB with rocuronium bromide increases the tolerance of acute normovolemic anemia. The underlying mechanism most likely involves a reduction of skeletal muscular $\mathrm{VO}_{2}$. During acellular treatment of an acute blood loss, NMB might play an adjuvant role in situations where profound stages of normovolemic anemia have to be tolerated (e.g. bridging an unexpected blood loss until blood products become available for transfusion).

Copyright $\odot 2011$ S. Karger AG, Basel

\section{Introduction}

The initial treatment of an acute blood loss usually consists of the infusion of crystalloid and/or colloidal solutions. The goal is the maintenance of normovolemia, the result is a dilution of the red cell mass remaining in the vasculature (acute normovolemic anemia). The term 'anemia tolerance' refers to both the patient's physiological ability to tolerate even profound stages of acute ane-

\section{KARGER}

Fax +41613061234 E-Mail karger@karger.ch www.karger.com
(C) 2011 S. Karger AG, Basel

$0014-312 X / 12 / 0481-0016 \$ 38.00 / 0$

Accessible online at:

www.karger.com/esr
Dr. med. Andreas Pape

Clinic of Anesthesiology, Intensive Care Medicine and Pain Management

J.W. Goethe University Hospital, Theodor-Stern-Kai 7

DE-60590 Frankfurt a.M. (Germany)

Tel. +49696301 83627, E-Mail a.pape@em.uni-frankfurt.de 
mia as well as to the anesthesiologist's willingness to accept low $\mathrm{Hb}$ concentrations [1].

Owing to the organism's individual anemia tolerance, tissue oxygenation is maintained, although $\mathrm{O}_{2}$ transport capacity decreases progressively with dilutional anemia. Acute anemia is initially compensated by increases in cardiac output and arteriovenous $\mathrm{O}_{2}$ extraction [2]. At physiologic $\mathrm{Hb}$ concentrations, $\mathrm{O}_{2}$ supply to the tissues $\left(\mathrm{DO}_{2}\right)$ exceeds total body $\mathrm{O}_{2}$ demand - reflected by $\mathrm{O}_{2}$ consumption $\left(\mathrm{VO}_{2}\right)$ under rest conditions - by the factor 3-4 [3]. Even when $\mathrm{DO}_{2}$ begins to decrease at lower $\mathrm{Hb}$ concentrations, $\mathrm{O}_{2}$ supply to the tissues is still sufficient to meet their $\mathrm{O}_{2}$ demand and $\mathrm{VO}_{2}$ remains constant over a wide range of decreasing $\mathrm{Hb}$ concentrations (supply independency of $\mathrm{VO}_{2}$ ). When $\mathrm{DO}_{2}$ falls below a critical value, the amount of $\mathrm{O}_{2}$ delivered to the tissues becomes insufficient to meet their $\mathrm{O}_{2}$ demand and $\mathrm{VO}_{2}$ starts to decline (supply dependency of $\left.\mathrm{VO}_{2}[4,5]\right) . \mathrm{Hb}_{\text {crit }}$ is the $\mathrm{Hb}$ concentration corresponding to the sudden decrease in $\mathrm{VO}_{2}$ and reflects the individual limit of anemia tolerance [6].

Neuromuscular blockade (NMB) is an integral part of the anesthetic management of a variety of surgical interventions. While NMB has been demonstrated to decrease total body energy expenditure and $\mathrm{VO}_{2}[7,8]$, to date, a potential influence on anemia tolerance has not been investigated. We hypothesized that NMB should increase the tolerance of acute normovolemic anemia - reflected by a significantly lower value of $\mathrm{Hb}_{\text {crit }}$ and a higher volume of blood allowed to be exchanged for hydroxyethyl starch (HES).

\section{Materials and Methods}

After approval by the local governmental review board, experiments were performed in 20 healthy farm-bred pigs of both sexes (body weight $25.8 \pm 3.7 \mathrm{~kg}$ ). All animals received good care in compliance with the Guide for the Care and Use of Laboratory Animals. Prior to the actual study, 5 pilot experiments were performed for dose finding (identification of an adequate dose of rocuronium bromide) and to assess potential effects of $\mathrm{NMB}$ on skeletal muscular $\mathrm{VO}_{2}\left(\mathrm{mVO}_{2}\right)$.

\section{Anesthesia and Ventilation}

Twelve hours before the experiments, the animals were denied food but had free access to water. After intramuscular premedication with $10 \mathrm{mg} / \mathrm{kg}$ ketamine and $1 \mathrm{mg} / \mathrm{kg}$ midazolam, anesthesia was induced by intravenous injection of $3 \mathrm{mg} / \mathrm{kg}$ propofol and 30 $\mu \mathrm{g} / \mathrm{kg}$ fentanyl. Anesthesia was maintained by continuous infusion of propofol $(0.16 \mathrm{mg} / \mathrm{kg} / \mathrm{min})$, midazolam $(0.01 \mathrm{mg} / \mathrm{kg} / \mathrm{min})$ and fentanyl $(0.8 \mu \mathrm{g} / \mathrm{kg} / \mathrm{min})$. Estimated fluid losses were replaced with a balanced electrolyte solution $(3 \mathrm{ml} / \mathrm{kg} / \mathrm{h})$. All trade names of anesthetics and infusion fluids applied are listed in the Appendix.

The animals' tracheas were orally intubated and their lungs were ventilated with ambient air at a rate of $14 \mathrm{cycles} / \mathrm{min}$ and a positive end-expiratory pressure of $5 \mathrm{~cm} \mathrm{H}_{2} \mathrm{O}$ (Servo 900B, Siemens Elema, Solna, Sweden). Tidal volume was individually adjusted to provide arterial normocapnia and was then maintained throughout the entire procedure. Body core temperature was kept constant using a warming pad.

\section{Pilot Experiments}

For preliminary assessment of $\mathrm{mVO}_{2}$, the right femoral artery and vein were dissected free from surrounding tissue. An ultrasonic flow probe (diameter $2 \mathrm{~mm}$, Transsonic, Ithaca, N.Y., USA) was placed around the femoral artery and the femoral vein was cannulated with an 18-gauge Teflon catheter (Leader Cath, Vygon, Ecouen, France), which was inserted retrograde for $15 \mathrm{~mm}$. An area of $3 \times 5 \mathrm{~cm}$ of the adductor muscle of the lower limb was dissected free from surrounding tissue for measurement of tissue $\mathrm{O}_{2}$ partial pressure. Thirty minutes after completion of surgical preparation, baseline values of $\mathrm{mVO}_{2}$ and tissue $\mathrm{O}_{2}$ partial pressure were obtained. Subsequently, the dissected skeletal muscle was subjected to tetanic electrical stimulation using a relaxometer device (TOF-watch, Organon, Oberschleissheim, Germany) and the second data set was recorded ('stimulation'). After a 30-min recovery period, a complete $\mathrm{NMB}$ was established with $3.78 \mathrm{mg} /$ $\mathrm{kg}$ of rocuronium bromide ('relaxation'). In pigs, the $\mathrm{ED}_{95}$ of rocuronium was determined to be $1.26 \mathrm{mg} / \mathrm{kg}$ [9], so that the used dose corresponded with the threefold $\mathrm{ED}_{95}$. The final data set was obtained 2 min after reversal of NMB with the tenfold dose (37.8 $\mathrm{mg} / \mathrm{kg}$ ) of sugammadex ('reversal'). Subsequently, the animals were killed by intracardial injection of saturated potassium chloride solution.

\section{Study Experiments}

Instrumentation and Monitoring

The animals were placed in supine position and a 5-lead electrocardiogram (II, V5) was used for detection of arrhythmias and ST segment changes. A double-lumen catheter (Arrow, Reading, Pa., USA) was inserted into the cranial vena cava and a SwanGanz catheter (Baxter, Irvine, Calif., USA) was floated into a branch of the pulmonary artery; 6 -french introducer sheaths were inserted into both the right femoral artery and vein, respectively. For continuous measurement of arterial blood pressure and cardiac output, a thermodilution catheter (Pulsion, Munich, Germany) was placed into the left femoral artery.

Experimental Protocol

Upon placement of the different measuring devices, a 60 -min stabilization period was allowed to elapse to achieve stable baseline conditions. The first data set ('baseline') was recorded, and appropriate neuromuscular transmission was visualized by assessment of the right foreleg extensor muscle contraction response to electric train-of-four stimulation (TOF-watch).

Thereafter, the animals were randomized to receive either rocuronium bromide or normal saline (Roc group, $\mathrm{n}=7 \mathrm{vs}$. Sal group, $\mathrm{n}=7)$. In the Roc group, the threefold $\mathrm{ED}_{95}(3.78 \mathrm{mg} / \mathrm{kg})$ was administered, followed by continuous infusion of $1 \mathrm{mg} / \mathrm{kg} /$ min. In the Sal group, the animals received the corresponding volumes of normal saline. The investigator remained blinded un- 
til the administration of rocuronium or saline was terminated and the second data set ('treatment') was registered.

Subsequently, an automated hemodilution protocol was initiated by isovolumic exchange of whole blood for HES (6\% HES $130 / 0.4,1 \mathrm{ml} / \mathrm{kg} / \mathrm{min}$ ). The target parameter was the animal's individual $\mathrm{Hb}_{\text {crit }}$ concentration, which was prospectively assessed in an investigator-independent manner (see below).

In the Roc group, the completeness of NMB was confirmed every $60 \mathrm{~s}$ during the entire hemodilution protocol (TOF stimulation of the foreleg extensor muscle). Therefore, the investigator needed to be unblinded at the initiation of the hemodilution protocol. When $\mathrm{Hb}_{\text {crit }}$ was met, the final data set was collected (' $\mathrm{H} \mathrm{b}_{\text {crit }}$ ') and the animals were killed by intracardial injection of saturated potassium chloride solution.

Assessment of $\mathrm{Hb}_{\text {crit }}$

$\mathrm{Hb}_{\text {crit }}$ is the correlate of the critical limitation of $\mathrm{DO}_{2}$, and marks the onset of total body $\mathrm{O}_{2}$ supply dependency. The corresponding decrease in $\mathrm{VO}_{2}$ was detected in an automated and investigator-independent manner: $\mathrm{VO}_{2}$ was measured every $60 \mathrm{~s}$ with a metabolic monitor (Delta-Trac II ${ }^{\mathrm{TM}}$ MBM-200, Datex-Engstrom, Helsinki, Finland). $\mathrm{VO}_{2}$ values were simultaneously recorded and computed with a specific software (DeltaCrit System) [10]. During the stabilization period, the DeltaCrit System included $\mathrm{VO}_{2}$ values into an online regression analysis and calculated mean and standard deviation. During the subsequent hemodilution period, every minutely obtained $\mathrm{VO}_{2}$ value was compared to the mean value predicted by the DeltaCrit System. When three consecutive $\mathrm{VO}_{2}$ values were outside the predefined range $(3 \times$ standard deviation of regression line; fig. 1), a significant decrease in $\mathrm{VO}_{2}$ was assumed and signaled by visual and acoustic computer alerts [10].

\section{Measurements}

Measurements of hemodynamic and $\mathrm{O}_{2}$-derived parameters were performed at 'baseline', 'treatment' and at ' $\mathrm{Hb}_{\text {crit }}$ '. Intravascular blood volume was determined at baseline using the 'wholeblood' method of the indocyanine green indicator dilution technique, which has already been described in detail elsewhere [11]. The pressure transducers of the cardiovascular catheters were connected with a multichannel recorder (Hugo-Sachs, MarchHugstetten, Germany) and measurement readings were recorded with a personal computer. Cardiac output was continuously assessed using the transpulmonary thermodilution technique (PICCO-Classic monitor, Pulsion, Munich, Germany). Arterial and mixed venous blood samples were withdrawn for blood gas analysis and assessment of $\mathrm{Hb}$ concentration (GEM 3000 and 682 CO-Oximeter, both Instrumentation Laboratory, Lexington, Mass., USA). Calculated parameters were determined as described in the Appendix.

\section{Statistics}

Statistical analysis was performed with the SAS 9.1 software package (SAS Institute, Cary, N.C., USA). Distribution of data was assessed with the Shapiro-Wilk test. Normally distributed parameters are presented as mean \pm standard deviation, nonnormally distributed parameters are displayed as median \pm semi-interquartile range.

In the case of normal distribution, the time effect on the different variables as well as differences between the groups at the



Fig. 1. Typical example of the continuous $\mathrm{VO}_{2}$ recording and identification of $\mathrm{Hb}_{\text {crit }}$. $\mathrm{VO}_{2}$ values collected during the 60 min were included in a linear regression analysis and mean and standard deviation were calculated. During the hemodilution protocol, every current $\mathrm{VO}_{2}$ value was compared with the mean value determined during the stabilization period. A critical limitation of $\mathrm{DO}_{2}$ was assumed, when three consecutive $\mathrm{VO}_{2}$ values fell below the lower $3 \sigma$ range.

investigated time points were tested by repeated analysis of variance. Post hoc analysis of differences detected with analysis of variance was performed with the Student-Newman-Keuls test.

In the case of nonnormal distribution, the time effect on the parameters as well as between-group differences were tested by analysis of variance on ranks. Post hoc analysis of differences detected with analysis of variance on ranks was performed with Tukey's test. For all parameters, statistical significance was accepted at $\mathrm{p}<0.05$.

The sample sizes were calculated on the basis of a postulated power of $85 \%$ and a variance of data observed in our previous studies with a similar experimental protocol.

\section{Results}

\section{Pilot Experiments}

Following neurostimulation of the lower limb adductor muscle, skeletal $\mathrm{mVO}_{2}$ was significantly increased (fig. 2).

The increase in $\mathrm{mVO}_{2}$ was accompanied by an increase in femoral arterial blood flow, while muscular $\mathrm{O}_{2}$ extraction rate did not change significantly (table 1).

After a 30-min recovery period, NMB with rocuronium bromide decreased $\mathrm{mVO}_{2}$ beyond the baseline level 


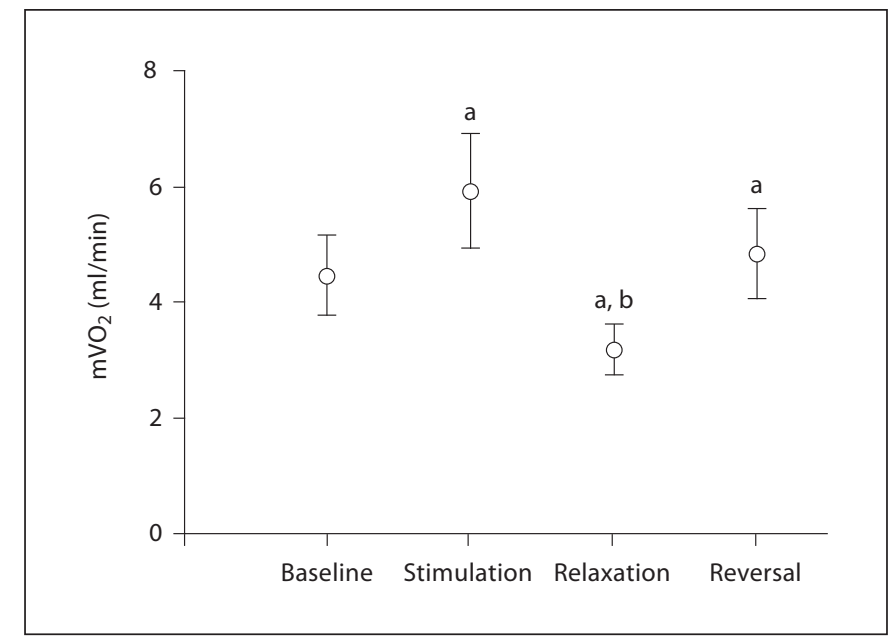

Fig. 2. Skeletal $\mathrm{mVO}_{2}$ determined in the lower limb adductor muscle (for the calculation of $\mathrm{mVO}_{2}$, see Appendix). $\mathrm{mVO}_{2}$ was assessed in the pilot study at the following time points: (1) after termination of surgical preparation ('baseline'), (2) after electrical neurostimulation of the muscle ('stimulation'), (3) after a 30-min recovery period and subsequent implementation of NMB ('relaxation'), and (4) after reversal of NMB with sugammadex ('reversal'). Neurostimulation was associated with a significant increase in $\mathrm{mVO}_{2}$. $\mathrm{NMB}$ decreased $\mathrm{mVO}_{2}$ beyond the baseline level, while the reversal of $\mathrm{NMB}$ returned $\mathrm{mVO}_{2}$ to baseline. ${ }^{\mathrm{a}} \mathrm{p}<0.05$ vs. previous time point, ${ }^{\mathrm{b}} \mathrm{p}<0.05$ vs. baseline.

( $p=0.011$; fig. 1 ), which was accompanied by a significant decrease in femoral arterial blood flow and a nonsignificant decrease in muscular $\mathrm{O}_{2}$ extraction rate (table 1). After pharmacologic reversal of $\mathrm{NMB}, \mathrm{mVO}_{2}$ and femoral arterial blood flow returned to baseline, which was paralleled by a significant increase in muscular $\mathrm{O}_{2}$ extraction rate (table 1).

Contrasting the effects on $\mathrm{mVO}_{2}, \mathrm{VO}_{2}$ remained unchanged after neurostimulation, NMB, and after the administration of sugammadex.

\section{Study Experiments}

Baseline Characteristics

No significant differences between the groups were observed at baseline (table 2).

\section{Effects of Treatment}

One animal developed a fatal allergic reaction immediately after injection of rocuronium bromide; this experiment was not included in data analysis as the animal did not meet the inclusion criterion (completion of hemodilution protocol).

Neuromuscular Blockade Increases Anemia Tolerance
Table 1. Pilot experiments: parameters of global and regional $\mathrm{O}_{2}$ transport

\begin{tabular}{lcccc}
\hline Parameter & Baseline & \multicolumn{2}{c}{ Stimulation Relaxation } & Reversal \\
\hline $\mathrm{HR}, \mathrm{min}^{-1}$ & $70 \pm 4$ & $67 \pm 5$ & $76 \pm 8$ & $74 \pm 4$ \\
$\mathrm{MAP}, \mathrm{mm} \mathrm{Hg}$ & $79 \pm 13$ & $81 \pm 5$ & $85 \pm 13$ & $77 \pm 10$ \\
$\mathrm{VO}_{2} \mathrm{I}, \mathrm{ml} \cdot \mathrm{min}^{-1} \cdot \mathrm{m}^{-2}$ & $237 \pm 13$ & $241 \pm 19$ & $236 \pm 20$ & $233 \pm 16$ \\
$\mathrm{Q}, \mathrm{ml} \cdot \mathrm{min}^{-1}$ & $89 \pm 8$ & $136 \pm 5^{*}$ & $84 \pm 8^{*}$ & $98 \pm 10^{*}$ \\
$\mathrm{SaO}, \%$ & $94 \pm 1$ & $94 \pm 2$ & $94 \pm 2$ & $94 \pm 2$ \\
$\mathrm{paO}_{2}, \mathrm{~mm} \mathrm{Hg}$ & $77 \pm 8$ & $76 \pm 10$ & $76 \pm 13$ & $78 \pm 10$ \\
$\mathrm{SfvO}_{2}, \%$ & $62 \pm 9$ & $63 \pm 6$ & $66 \pm 2$ & $57 \pm 4^{*}$ \\
$\mathrm{pfvO}_{2}, \mathrm{~mm} \mathrm{Hg}$ & $33 \pm 3$ & $36 \pm 3$ & $35 \pm 3$ & $32 \pm 2^{*}$ \\
$\mathrm{tpO}_{2}, \mathrm{~mm} \mathrm{Hg}$ & $30 \pm 9$ & $39 \pm 23$ & $39 \pm 11$ & $34 \pm 24$ \\
$\mathrm{mO}_{2}-\mathrm{ER}, \%$ & $35 \pm 9$ & $33 \pm 6$ & $29 \pm 4$ & $39 \pm 5^{*}$ \\
\hline
\end{tabular}

$\mathrm{HR}=$ Heart rate; $\mathrm{MAP}=$ mean arterial pressure; $\mathrm{VO}_{2} \mathrm{I}=$ total body $\mathrm{O}_{2}$ consumption indexed to body surface area; $\mathrm{Q}=$ femoral arterial blood flow; $\mathrm{SaO}_{2}, \mathrm{paO}_{2}, \mathrm{SfvO}_{2}, \mathrm{pfvO}_{2}=$ arterial and femoral venous $\mathrm{O}_{2}$ saturation and $\mathrm{O}_{2}$ partial pressure; $\mathrm{tpO}_{2}=$ tissue $\mathrm{O}_{2}$ partial pressure; $\mathrm{mO}_{2} \mathrm{ER}=$ muscular $\mathrm{O}_{2}$ extraction rate. ${ }^{*} \mathrm{p}<$ 0.05 vs. previous.

While the injection of normal saline was devoid of any hemodynamic effect, the administration of rocuronium bromide was associated with significant increases in heart rate and mean pulmonary artery pressure and nonsignificant increases in cardiac index (CI) and pulmonary capillary wedge pressure. Compared with the Sal group, the mean pulmonary artery pressure was higher and the systemic vascular resistance index was lower in animals having received rocuronium bromide $(\mathrm{p}<0.05$; table 2).

Although the $\mathrm{O}_{2}$ extraction rate was decreased in the Roc group ( $p<0.05$ vs. baseline and vs. Sal), NMB did not exert a significant change of total body $\mathrm{VO}_{2}$ (fig. 3). However, in 5 of the 7 animals of the Roc group, $\mathrm{VO}_{2}$ decreased slightly, while $\mathrm{VO}_{2}$ only decreased in 2 animals of the Sal group. As a consequence, the change of $\mathrm{VO}_{2}$ relative to baseline $\left(\Delta \mathrm{VO}_{2}\right)$ had a negative sign in the Roc group $\left(\Delta \mathrm{VO}_{2}:-1.7 \pm 0.8 \%\right)$ and was positive in the Sal group (3.2 $\pm 1.9 \%$; fig. 2$)$.

Primary Endpoint: $\mathrm{Hb}_{\text {crit }}$

NMB with rocuronium bromide enabled a more extensive blood for HES exchange: in the Roc group, 2,081 \pm $449 \mathrm{ml}$ of blood had been exchanged (vs. 1,433 $\pm 501 \mathrm{ml}$ in the Sal group, $\mathrm{p}=0.014$ ) until $\mathrm{Hb}_{\text {crit }}$ was met and the hemodilution protocol was terminated. As a consequence, a significantly lower value of $\mathrm{Hb}_{\text {crit }}$ was attained in the Roc group $(2.4 \pm 0.5 \mathrm{~g} / \mathrm{dl}$ vs. $3.2 \pm 0.7 \mathrm{~g} / \mathrm{dl}, \mathrm{p}=0.015$; fig. 4$)$.

Eur Surg Res 2012;48:16-25 
Table 2. Parameters of central hemodynamics and $\mathrm{O}_{2}$ transport obtained at baseline, after treatment with Roc or Sal, and at the $\mathrm{Hb}_{\text {crit }}$

\begin{tabular}{|c|c|c|c|c|}
\hline Parameter & Group & Baseline & Treatment & $\mathrm{Hb}_{\text {crit }}$ \\
\hline BVI & Roc & $81 \pm 13$ & n.d. & n.d. \\
\hline $\mathrm{ml} \cdot \mathrm{m}^{-2}$ & Sal & $72 \pm 7$ & n.d. & n.d. \\
\hline Temperature & Roc & $37.5 \pm 1.1$ & $37.4 \pm 1.4$ & $37.1 \pm 1.0$ \\
\hline${ }^{\circ} \mathrm{C}$ & Sal & $37.3 \pm 0.8$ & $37.2 \pm 0.5$ & $37.0 \pm 0.8$ \\
\hline$\overline{\mathrm{HR}}$ & Roc & $77 \pm 7$ & $93 \pm 12^{\mathrm{a}}$ & $125 \pm 11^{\mathrm{a}}$ \\
\hline $\min ^{-1}$ & Sal & $79 \pm 7$ & $83 \pm 7$ & $117 \pm 19^{a}$ \\
\hline$\overline{\mathrm{MAP}}$ & Roc & $73 \pm 10$ & $76 \pm 12$ & $49 \pm 11^{\mathrm{a}}$ \\
\hline $\mathrm{mm} \mathrm{Hg}$ & Sal & $86 \pm 19$ & $82 \pm 10$ & $73 \pm 8^{\mathrm{a}, \mathrm{b}}$ \\
\hline$\overline{\mathrm{MPAP}}$ & Roc & $24 \pm 4$ & $30 \pm 5^{\mathrm{a}, \mathrm{b}}$ & $28 \pm 1$ \\
\hline$\underline{\mathrm{mm} \mathrm{Hg}}$ & Sal & $23 \pm 7$ & $24 \pm 7$ & $29 \pm 7^{\mathrm{a}}$ \\
\hline PCWP & Roc & $5.3 \pm 2.2$ & $8.2 \pm 3.2$ & $7.4 \pm 3.3$ \\
\hline$\underline{\mathrm{mm} \mathrm{Hg}}$ & Sal & $5.0 \pm 2.9$ & $5.6 \pm 3.8$ & $7.7 \pm 4.7^{\mathrm{a}}$ \\
\hline$\overline{\mathrm{CI}}$ & Roc & $3.9 \pm 0.6$ & $4.6 \pm 0.9$ & $7.3 \pm 1.1^{\mathrm{a}}$ \\
\hline $1 \cdot \min ^{-1} \cdot \mathrm{m}^{2}$ & Sal & $3.5 \pm 0.2$ & $3.9 \pm 0.4$ & $7.2 \pm 1.1^{\mathrm{a}}$ \\
\hline$\overline{\text { SVI }}$ & Roc & $53 \pm 4$ & $49 \pm 4$ & $57 \pm 9$ \\
\hline$\underline{\mathrm{ml} \cdot \mathrm{m}^{-2}}$ & Sal & $45 \pm 4$ & $47 \pm 6$ & $59 \pm 4^{\mathrm{a}}$ \\
\hline$\overline{\mathrm{CVP}}$ & Roc & $5.5 \pm 4.1$ & $5.8 \pm 2.8$ & $7.6 \pm 2.0$ \\
\hline $\mathrm{mm} \mathrm{Hg}$ & Sal & $6.5 \pm 3.0$ & $5.6 \pm 2.9$ & $8.9 \pm 4.1$ \\
\hline$\overline{\text { SVR }}$ & Roc & $1,795 \pm 241$ & $1,319 \pm 388$ & $627 \pm 474^{\mathrm{a}}$ \\
\hline $\operatorname{dyn}^{-1} \cdot \mathrm{s}^{-1} \cdot \mathrm{cm}^{-5}$ & Sal & $1,660 \pm 183$ & $1,554 \pm 134^{b}$ & $742 \pm 119^{a}$ \\
\hline PVRI & Roc & $383 \pm 48$ & $431 \pm 91$ & $248 \pm 43$ \\
\hline $\operatorname{dyn}^{-1} \cdot \mathrm{s}^{-1} \cdot \mathrm{cm}^{-5}$ & Sal & $421 \pm 116$ & $378 \pm 105$ & $218 \pm 26^{a}$ \\
\hline$\overline{\mathrm{CPP}}$ & Roc & $51 \pm 10$ & $53 \pm 12$ & $25 \pm 5^{a}$ \\
\hline $\mathrm{mm} \mathrm{Hg}$ & Sal & $64 \pm 18$ & $58 \pm 8$ & $45 \pm 8^{\mathrm{a}, \mathrm{b}}$ \\
\hline$\overline{\mathrm{VO}_{2} \mathrm{I}}$ & Roc & $231 \pm 20$ & $228 \pm 22$ & $199 \pm 28^{\mathrm{a}}$ \\
\hline $\mathrm{ml}^{-1} \cdot \min ^{-1} \cdot \mathrm{m}^{-2}$ & Sal & $241 \pm 18$ & $244 \pm 14$ & $226 \pm 16^{\mathrm{a}}$ \\
\hline$\overline{\mathrm{DO}_{2} \mathrm{I}}$ & Roc & $425 \pm 78$ & $496 \pm 74$ & $227 \pm 94^{\mathrm{a}, \mathrm{b}}$ \\
\hline $\mathrm{ml}^{-1} \cdot \mathrm{min}^{-1} \cdot \mathrm{m}^{-2}$ & Sal & $374 \pm 8$ & $429 \pm 62$ & $327 \pm 55^{\mathrm{a}}$ \\
\hline $\mathrm{paO}_{2}$ & Roc & $99 \pm 13$ & $96 \pm 14$ & $95 \pm 8$ \\
\hline $\mathrm{mm} \mathrm{Hg}$ & Sal & $105 \pm 12$ & $110 \pm 8$ & $113 \pm 23$ \\
\hline $\mathrm{paCO}_{2}$ & Roc & $34 \pm 4$ & $35 \pm 4$ & $35 \pm 2$ \\
\hline $\mathrm{mm} \mathrm{Hg}$ & Sal & $33 \pm 3$ & $33 \pm 3$ & $34 \pm 3$ \\
\hline$\overline{\mathrm{CaO}_{2}}$ & Roc & $10.8 \pm 1.1$ & $11.1 \pm 1.0$ & $3.5 \pm 0.7^{\mathrm{a}}$ \\
\hline$\underline{\mathrm{ml} \cdot \mathrm{dl}^{-1}}$ & Sal & $10.8 \pm 0.6$ & $10.9 \pm 0.9$ & $4.6 \pm 1.0^{\mathrm{a}, \mathrm{b}}$ \\
\hline$\overline{\mathrm{SvO}_{2}}$ & Roc & $57 \pm 10$ & $62 \pm 8^{\mathrm{a}}$ & $53 \pm 12^{\mathrm{a}}$ \\
\hline$\%$ & Sal & $53 \pm 8$ & $56 \pm 9$ & $61 \pm 18$ \\
\hline$\overline{\mathrm{O}_{2}-\mathrm{ER}}$ & Roc & $43 \pm 10$ & $34 \pm 6^{\mathrm{a}, \mathrm{b}}$ & $50 \pm 11^{\mathrm{a}}$ \\
\hline$\%$ & Sal & $47 \pm 7$ & $41 \pm 8$ & $41 \pm 16$ \\
\hline \multirow[t]{2}{*}{$\overline{\mathrm{pH}}$} & Roc & $7.55 \pm 0.08$ & $7.49 \pm 0.11$ & $7.47 \pm 0.03^{\mathrm{a}, \mathrm{b}}$ \\
\hline & Sal & $7.57 \pm 0.04$ & $7.58 \pm 0.04$ & $7.52 \pm 0.04^{\mathrm{a}}$ \\
\hline \multirow{2}{*}{$\begin{array}{l}\text { Base excess } \\
\mathrm{mmol} \cdot \mathrm{l}^{-1}\end{array}$} & Roc & $7.5 \pm 4.0$ & $3.5 \pm 5.5$ & $1.4 \pm 2.4^{\mathrm{a}, \mathrm{b}}$ \\
\hline & Sal & $8.4 \pm 2.4$ & $8.3 \pm 2.0$ & $4.6 \pm 1.8^{\mathrm{a}}$ \\
\hline \multirow{2}{*}{$\begin{array}{l}\text { Lactate } \\
\mathrm{mmol} \cdot \mathrm{l}^{-1}\end{array}$} & Roc & $1.7 \pm 1.0$ & $1.7 \pm 1.0$ & $2.1 \pm 1.0$ \\
\hline & Sal & $2.1 \pm 0.6$ & $2.0 \pm 0.6$ & $2.0 \pm 0.8$ \\
\hline
\end{tabular}

BVI = Blood volume indexed to body surface area; HR = heart rate; $\mathrm{MAP}=$ mean arterial pressure; $\mathrm{MPAP}=$ mean pulmonary artery pressure; $\mathrm{PCWP}=$ pulmonary capillary wedge pressure; $\mathrm{SVI}=$ stroke volume index; CVP = central venous pressure; SVRI and PVRI = systemic and pulmonary vascular resistance index; $\mathrm{CPP}=$ coronary perfusion pressure; $\mathrm{DO}_{2} \mathrm{I}=\mathrm{O}_{2}$ delivery indexed to body surface area; $\mathrm{paO}_{2}=$ arterial $\mathrm{O}_{2}$ partial pressure; $\mathrm{CaO}_{2}=$ arterial $\mathrm{O}_{2}$ content; $\mathrm{SvO}_{2}=$ mixed venous $\mathrm{O}_{2}$ saturation; $\mathrm{O}_{2} \mathrm{ER}=\mathrm{O}_{2}$ extraction rate. Roc group, $\mathrm{n}=7$; Sal group, $\mathrm{n}=7$. ${ }^{\mathrm{a}} \mathrm{p}<0.05$ difference vs. baseline; ${ }^{\mathrm{b}} \mathrm{p}<0.05$ difference between the groups.
Secondary Endpoints: Hemodynamics and $\mathrm{O}_{2}$ Transport

During induction of critical normovolemic anemia, heart rate and CI increased in both groups by 38 and $67 \%$ ( $\mathrm{p}<0.05$ vs. baseline), whereas mean aortic pressure and coronary perfusion pressure decreased by 23 and 37\%, respectively ( $\mathrm{p}<0.05$ vs. baseline). PVRI decreased by $10 \%$ in the Roc group (nonsignificant vs. baseline) and by $38 \%$ in the Sal group ( $\mathrm{p}<0.05$ vs. baseline). Furthermore, hemodilution was associated with a decrease of $\mathrm{CaO}_{2}$, $\mathrm{DO}_{2}, \mathrm{pH}$ and BE by $64,59,1$ and $49 \%$ ( $\mathrm{p}<0.05$ vs. baseline). The $\mathrm{O}_{2}$ extraction rate only increased in the Roc group $(\mathrm{p}<0.05)$, which was accompanied by decreases in $\mathrm{SvO}_{2}$ and $\mathrm{pvO}_{2}(\mathrm{p}<0.05)$.

At $\mathrm{Hb}_{\text {crit }}$, the following differences between the groups were observed: arterial blood pressure was significantly lower in the Roc group, resulting in lower values of mean aortic pressure and coronary perfusion pressure $(\mathrm{p}<$ 0.05). Due to the lower $\mathrm{Hb}_{\text {crit }}$ in the Roc group, $\mathrm{CaO}_{2}$ and $\mathrm{DO}_{2}$ indexed to the body surface area were significantly lower than in the Sal group. The lower values of $\mathrm{pH}$ and base excess $(p<0.05)$ reflect dilutional acidosis related to a more profound degree of hemodilution in the Roc group.

\section{Discussion}

The main result of the present study is that NMB with rocuronium bromide increased the tolerance of acute normovolemic anemia, as indicated by a significantly lower value of $\mathrm{Hb}_{\text {crit }}$, and a higher volume of blood exchanged for HES until $\mathrm{Hb}_{\text {crit }}$ was met.

$\mathrm{Hb}_{\text {crit }}$ represents the ultimate limit of anemia tolerance, i.e., the $\mathrm{Hb}$ concentration corresponding with a critical limitation of $\mathrm{DO}_{2}$. When $\mathrm{Hb}$ falls short of this critical value, the amount of $\mathrm{O}_{2}$ delivered to the tissues becomes insufficient to meet their $\mathrm{O}_{2}$ demand and $\mathrm{VO}_{2}$ starts to decline (onset of $\mathrm{O}_{2}$ supply dependency of $\mathrm{VO}_{2}$ ) $[4,5]$. In our previous experimental studies, critical normovolemic anemia was associated with $100 \%$ mortality if no further treatment (e.g. elevation of $\mathrm{FiO}_{2}$, transfusion of red blood cells, administration of catecholamines, infusion of artificial $\mathrm{O}_{2}$ carriers) was instantaneously initiated at $\mathrm{Hb}_{\text {crit }}[12-15]$.

$\mathrm{Hb}_{\text {crit }}$ has been chosen as the primary endpoint in several experimental studies investigating the impact of several interventions on the tolerance limit of acute anemia and was usually found at values between 1.6 and $3 \mathrm{~g} / \mathrm{dl}$ (table 3). Consistently, the value of $\mathrm{Hb}_{\text {crit }}$ in the Roc group 
Fig. 3. Change of $\mathrm{VO}_{2}$ after treatment displayed as mean difference relative to baseline $\left(\Delta \mathrm{VO}_{2}\right)$. In 5 out of 7 animals of the Roc group, $\mathrm{VO}_{2}$ decreased slightly $\left(\Delta \mathrm{VO}_{2}\right.$ $-1.7 \pm 0.8 \%$ ), while in the Sal group, $\mathrm{VO}_{2}$ only decreased in 2 out of 7 animals $\left(\Delta \mathrm{VO}_{2}\right.$ $3.2 \pm 1.9 \%, \mathrm{p}<0.05$ vs. Roc group).

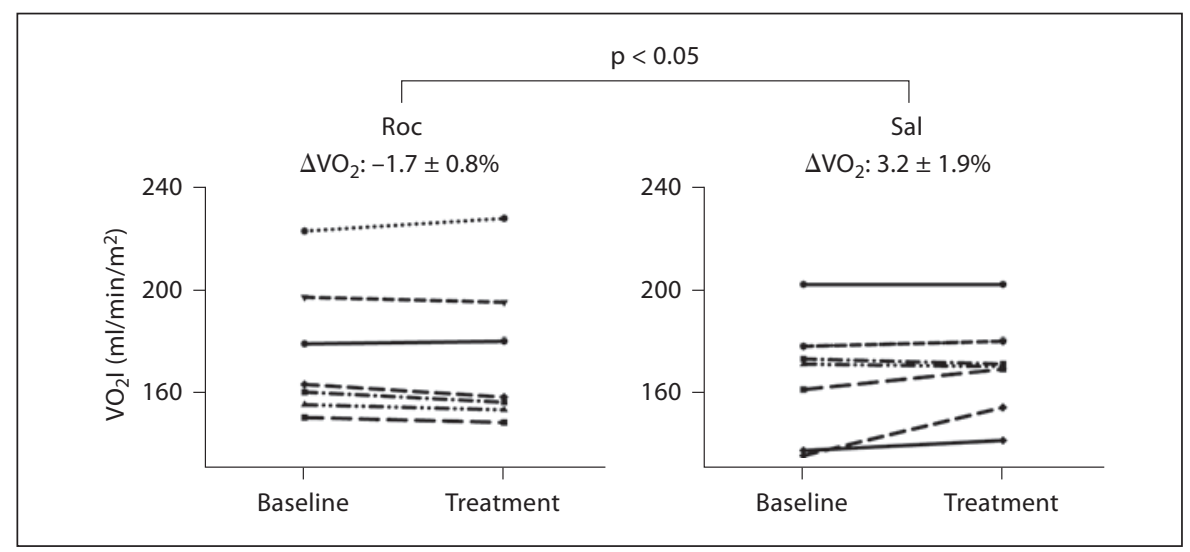

$(2.4 \pm 0.5 \mathrm{~g} / \mathrm{dl})$ is comparable to that described in paralyzed animals $[13,15-19]$, while the values of $\mathrm{Hb}_{\text {crit }} \mathrm{Ob}$ tained in nonparalyzed animals are similar to $\mathrm{Hb}_{\text {crit }} \mathrm{Ob}$ served in the Sal group $[4,12]$.

In several experimental studies, a decrease in $\mathrm{Hb}_{\text {crit }}$ demonstrated that anemia tolerance is increased by (1) hypothermia (moderate reduction of body core temperature reduces total body $\mathrm{O}_{2}$ demand [16]), (2) hyperoxic ventilation (bioavailability of physically dissolved $\mathrm{O}_{2}$ is excellent in profound anemia $[12,17,18])$, (3) infusion of norepinephrine (stabilization of coronary perfusion pressure during hemodilution [13]), and (4) artificial $\mathrm{O}_{2}$ carriers (maintenance of $\mathrm{CaO}_{2}$ despite reduced hematocrit $[19,20])$. In contrast, anemia tolerance is decreased by (1) hypovolemia (reduction of microcirculatory $\mathrm{O}_{2}$ supply), (2) profound anesthesia (pharmacologic reduction of the cardiac output response to hemodilution [21, 22]) and (3) by coronary artery disease (reduced coronary flow reserve [23]).

During general anesthesia, NMB is usually applied to facilitate orotracheal intubation and mechanical ventilation and many surgical procedures (e.g. abdominal or thoracic surgery) require NMB. Whether the pharmacologic reduction of skeletal muscular tone by NMB has an impact on anemia tolerance has been of minor interest and has not yet been investigated.

Considering that skeletal muscular mass comprises $30-40 \%$ of total body mass [24] and that the cross-bridge cycle of muscular contraction is highly energy-dependent [25], it should be expected that NMB reduces skeletal $\mathrm{mVO}_{2}$ and should therefore decrease total body $\mathrm{O}_{2}$ demand.

In part, this assumption is supported by our data. Actually, the results of our pilot experiments clearly demon-

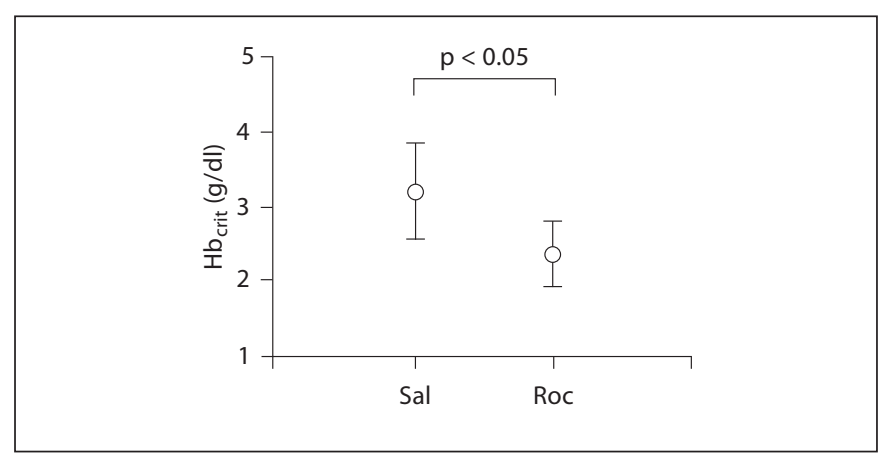

Fig. 4. $\mathrm{Hb}_{\text {crit }}$ investigated as the primary endpoint of the present study. As the hemodilution protocol could be performed more extensively in the Roc group, a critical limitation of total body $\mathrm{O}_{2}$ supply was met at a significantly lower $\mathrm{Hb}_{\text {crit }}(2.4 \pm 0.5 \mathrm{~g} / \mathrm{dl}$ vs. $3.2 \pm 0.7 \mathrm{~g} / \mathrm{dl}, \mathrm{p}<0.05 \mathrm{vs}$. Sal).

strate that $\mathrm{NMB}$ decreased $\mathrm{mVO}_{2}$, regional blood flow to the skeletal muscle and muscular $\mathrm{O}_{2}$ extraction beyond their baseline values. Consistently, the reversal of NMB with sugammadex - a $\gamma$-cyclodextrin-based chelator with a specific affinity to steroidal relaxants (rocuronium $>$ vecuronium $>$ pancuronium) [26] - elevated these parameters and their values returned to the baseline level (fig. 2; table 1).

NMB had only a moderate effect on the total body level. After administration of rocuronium bromide, total body $\mathrm{O}_{2}$ extraction decreased and the negative $\mathrm{VO}_{2}$ difference to baseline $\left(\Delta \mathrm{VO}_{2}\right)$ in the Roc group (vs. a positive value of $\Delta \mathrm{VO}_{2}$ in the Sal group) indicates a slight effect on total body $\mathrm{VO}_{2}$ (fig. 3). Apart from that, rocuronium bromide elicited notable hemodynamic effects, as very high doses were needed to achieve complete NMB (table 2). 
Table 3. Limits of acute normovolemic anemia as reflected by the individual $\mathrm{Hb}_{\text {crit }}$ in different species

\begin{tabular}{|c|c|c|c|c|c|c|}
\hline Author & Species & Anesthesia & $\mathrm{FiO}_{2}$ & $\begin{array}{l}\text { Plasma } \\
\text { substitute }\end{array}$ & Identification of $\mathrm{Hb}_{\text {crit }}$ & $\begin{array}{l}\mathrm{Hb}_{\mathrm{crit}} \\
\mathrm{g} \cdot \mathrm{dl}^{-1}\end{array}$ \\
\hline Fontana et al. [37] & man (child) & isoflurane, sufentanil, vecuronium & 1.0 & albumin & decay of $\mathrm{VO}_{2}$ (retrospectively) & 2.1 \\
\hline $\begin{array}{l}\text { Van Woerkens } \\
\text { et al. [38] }\end{array}$ & $\begin{array}{l}\text { man } \\
\text { (84 years) }\end{array}$ & enflurane, fentanyl, pancuronium & 0.4 & gelatin & decay of $\mathrm{VO}_{2}$ (retrospectively) & 4 \\
\hline Zollinger et al. [39] & $\begin{array}{l}\operatorname{man} \\
\text { (58 years) }\end{array}$ & propofol, fentanyl, pancuronium & 1.0 & gelatin & ST segment depression & $\sim 1.1$ \\
\hline Cain [4] & $\operatorname{dog}$ & pentobarbital & 0.21 & dextran & decay of $\mathrm{VO}_{2}$ (retrospectively) & 3.3 \\
\hline $\begin{array}{l}\text { Perez-de-Sá } \\
\text { et al. [16] }\end{array}$ & pig & $\begin{array}{l}\text { isoflurane, fentanyl, midazolam, } \\
\text { vecuronium }\end{array}$ & 0.5 & dextran & decay of $\mathrm{VO}_{2}$ (retrospectively) & $2.3 \pm 0.2$ \\
\hline Meier et al. [12] & pig & propofol, fentanyl & 0.21 & HES & decay of $\mathrm{VO}_{2}$ (prospectively) & $3.1 \pm 0.4$ \\
\hline Pape et al. [17] & pig & $\begin{array}{l}\text { propofol, fentanyl, midazolam, } \\
\text { pancuronium }\end{array}$ & 0.21 & HES & decay of $\mathrm{VO}_{2}$ (prospectively) & $2.4 \pm 0.4$ \\
\hline Kemming et al. [18] & pig & midazolam, morphine, pancuronium & 0.21 & HES & ST segment depression & $2.6 \pm 0.3$ \\
\hline Meisner et al. [19] & pig & diazepam, morphine, pancuronium & 0.21 & albumin & ST segment depression & $2.0 \pm 0.8$ \\
\hline Meier et al [13] & pig & propofol, fentanyl, pancuronium & 0.21 & HES & decay of $\mathrm{VO}_{2}$ (prospectively) & $2.6 \pm 0.4$ \\
\hline Pape et al. [15] & $\operatorname{dog}$ & $\begin{array}{l}\text { propofol, midazolam, fentanyl, } \\
\text { pancuronium }\end{array}$ & 0.21 & HES & decay of $\mathrm{VO}_{2}$ (prospectively) & $2.7 \pm 0.5$ \\
\hline Van der Linden [40] & $\operatorname{dog}$ & thiopental, ketamine, pancuronium & 0.21 & $\begin{array}{l}\text { HES versus } \\
\text { gelatin }\end{array}$ & decay of $\mathrm{VO}_{2}$ (retrospectively) & $\begin{array}{l}3.6 \pm 0.8 \\
3.5 \pm 1.5\end{array}$ \\
\hline Van der Linden [21] & $\operatorname{dog}$ & $\begin{array}{l}\text { thiopental, ketamine (high dose), } \\
\text { pancuronium thiopental, } \\
\text { ketamine (low dose), pancuronium }\end{array}$ & 0.21 & HES & decay of $\mathrm{VO}_{2}$ (retrospectively) & $\begin{array}{l}3.7 \pm 1.4 \\
2.5 \pm 0.6\end{array}$ \\
\hline
\end{tabular}

While the transient increase in pulmonary vascular resistance, mean pulmonary artery pressure and pulmonary capillary wedge pressure might have been evoked by histamine release, the increases in heart rate and CI are probably caused by vagolytic effects, which have been described for steroidal relaxants like pancuronium or rocuronium [27].

According to Fick's principle, the decrease in total body $\mathrm{O}_{2}$ extraction immediately after administration of rocuronium might be interpreted as a response to increased CI - always presumed that $\mathrm{VO}_{2}$ remains constant. However, Muldoon and Theye [28] reported already in 1969 that whole-body $\mathrm{VO}_{2}$ was decreased in dogs paralyzed with d-tubocurarine, and some clinical studies investigating the effects of $\mathrm{NMB}$ on $\mathrm{VO}_{2}$ reported a reduction of total-body $\mathrm{VO}_{2}$ and energy expenditure by $\mathrm{NMB}$ in sedated and mechanically ventilated children [8] and in adults suffering acute respiratory failure [7], severe cerebral trauma [29] or burn injuries [30]. Inconsistently, other investigators found no effects of $\mathrm{NMB}$ on $\mathrm{VO}_{2}$ in deeply sedated intensive care unit patients (Ramsay score 5) [31] or in anesthetized patients undergoing cardiac surgery [32].
The potential of $\mathrm{NMB}$ to reduce total body $\mathrm{VO}_{2}$ might therefore depend on the depth of anesthesia. The anesthesia regimen applied in the present study (propofol, midazolam and fentanyl) has already been used in several of our previous investigations $[13,14,17]$. To the author's experience, this anesthesia regimen has proven appropriate for pigs, as it provided sufficient anesthetic depth without severely compromising cardiovascular function.

Under the anesthetic regimen applied in the present study, skeletal muscular activity did not substantially contribute to total body $\mathrm{VO}_{2}$, although $\mathrm{NMB}$ did reduce $\mathrm{mVO}_{2}$, muscular $\mathrm{O}_{2}$ extraction and regional blood flow to the skeletal muscle.

Physiologically, blood flow to and within the skeletal muscle is regulated by the endothelial/vascular smooth muscle unit, which permits the physiological adaptation of regional $\mathrm{O}_{2}$ delivery to the actual metabolic demand [33]. At the site of microcirculation, convective and diffusive $\mathrm{O}_{2}$ transport is therefore enhanced in the contracting muscle, when compared with the skeletal muscle at rest [34]. Moreover, blood flow to the working muscle seems to be augmented during acute anemia: in humans 
undergoing moderate hemodilution and submaximal muscular exercise, the increase in muscular blood flow was more strongly pronounced than in controls with physiologic arterial $\mathrm{O}_{2}$ content [35]. This finding suggests that particularly in acute anemia, the elimination of muscular activity reduces skeletal muscular blood flow, thereby enabling a redistribution of $\mathrm{O}_{2}$ delivery in favor of vital organs.

In summary, our data indicate that complete NMB increased the tolerance of acute normovolemic anemia in anesthetized pigs. The underlying mechanism most likely involves a reduction of skeletal muscular metabolic $\mathrm{O}_{2}$ demand. Although paralyzed individuals may tolerate significantly lower $\mathrm{Hb}$ concentrations than nonparalyzed, a blood transfusion in clinical practice would usually be initiated before anemia tolerance is exhausted, especially since the individual anemia tolerance is strongly influenced by comorbidity including cardiovascular diseases or critical illness. However, an allogeneic blood transfusion may occasionally be impossible (e.g. refusal of blood transfusion for religious reasons, bridging an unexpected massive blood loss until compatible blood products become available for transfusion, prehospital trauma care) and very severe levels of acute normovolemic anemia have to be tolerated in these particular situations. In such extreme conditions, the augmentation of anemia tolerance by NMB might play an adjuvant role in maintaining $\mathrm{DO}_{2}$ and oxygenation of vital organs despite extremely low $\mathrm{Hb}$ levels.

\section{Acknowledgments}

The authors would like to thank Mr. W. Daut and his team for their excellent animal care and Mr. H. Winkelmeier for his valuable technical assistance. Sincere thanks are given to Dr. H.-J. Wilke (D.E.A.A.) for reviewing the manuscript. The study was sponsored by a research grant from Organon Inc., Oberschleissheim, Germany.

\section{Appendix}

Calculations

Body surface area (BSA) was calculated according to Holt et al. [36] from body weight (BW) and a species-dependent constant ( $\mathrm{k}=9$ for pigs):

$$
B S A=k \cdot B W^{\frac{2}{3}}\left(m^{2}\right)
$$

CI was calculated as:

$$
C I=\frac{C O}{B S A}\left(\frac{l}{\mathrm{~min} \cdot \mathrm{m}^{2}}\right)
$$

where $\mathrm{CO}=$ cardiac output

Stroke volume index (SVI) was calculated as:

$$
S V I=\frac{C I}{H R}\left(\frac{l}{m^{2}}\right)
$$

where $\mathrm{HR}=$ heart rate.

Systemic and pulmonary vascular resistance indices were calculated as:

$$
S V R I=\frac{(M A P-C V P) \cdot 79.9}{C I}\left(\frac{d y n \cdot s}{\mathrm{~cm}^{5} \cdot \mathrm{m}^{2}}\right)
$$

and

$$
P V R I=\frac{(M P A P-P C W P) \cdot 79.9}{C I}\left(\frac{d y n \cdot s}{\mathrm{~cm}^{5} \cdot \mathrm{m}^{2}}\right)
$$

respectively, where SVRI = systemic vascular resistance index, $\mathrm{PVRI}=$ pulmonary vascular resistance index, $\mathrm{MAP}=$ mean aortic pressure, $\mathrm{CVP}=$ central venous pressure, $\mathrm{MPAP}=$ mean pulmonary artery pressure, and PCWP = pulmonary capillary wedge pressure.

Coronary perfusion pressure $(\mathrm{CPP})$ was calculated as:

$$
\text { CPP = DAP - PCWP (mm Hg), }
$$

where $\mathrm{CPP}=$ coronary perfusion pressure, $\mathrm{DAP}=$ diastolic aortic pressure, and PCWP = pulmonary capillary wedge pressure.

Arterial and mixed venous $\mathrm{O}_{2}$ contents $\left(\mathrm{CaO}_{2}\right.$ and $\left.\mathrm{CvO}_{2}\right)$ were calculated as:

$$
\mathrm{CaO}_{2}=1.34 \cdot[\mathrm{Hb}] \cdot \mathrm{SaO}_{2}+0.0031 \cdot \mathrm{paO}_{2}\left(\frac{\mathrm{ml}}{\mathrm{dl}}\right)
$$

and

$$
\mathrm{CvO}_{2}=1.34 \cdot[\mathrm{Hb}] \cdot \mathrm{SvO}_{2}+0.0031 \cdot \mathrm{pvO}_{2}\left(\frac{\mathrm{ml}}{\mathrm{dl}}\right)
$$

where $\mathrm{SaO}_{2}$ and $\mathrm{SvO}_{2}=$ arterial and mixed venous $\mathrm{O}_{2}$ saturation and $\mathrm{paO}_{2}$ and $\mathrm{pvO}_{2}=$ arterial and mixed venous $\mathrm{O}_{2}$ partial pressure.

$\mathrm{O}_{2}$ delivery was indexed to BSA:

$$
\mathrm{DO}_{2} \mathrm{I}=\mathrm{CI} \cdot \mathrm{CaO}_{2}\left(\frac{\mathrm{ml}}{\mathrm{min} \cdot \mathrm{m}^{2}}\right)
$$

$\mathrm{O}_{2}$ extraction ratio was calculated as:

$\mathrm{O}_{2}-\mathrm{ER}=\frac{\mathrm{CaO}_{2}-\mathrm{CvO}}{\mathrm{CaO}} \cdot 100(\%)$

The relative difference of $\mathrm{VO}_{2}$ to baseline after treatment was calculated as

$$
\Delta V O_{2}=\left(\frac{V O_{2 \text { Treatment }}}{V O_{2 \text { Basline }}}\right) \cdot 100-100(\%)
$$

Skeletal $\mathrm{mVO}_{2}$ was calculated as:

$$
m V_{2}=Q \cdot \frac{\left(\mathrm{CaO}_{2}-\mathrm{CfvO}_{2}\right)}{100}\left(\frac{\mathrm{ml}}{\min }\right)
$$

where $\mathrm{Q}=$ femoral arterial blood flow, $\mathrm{CaO}_{2}$ and $\mathrm{CfvO}_{2}=$ arterial and femoral venous $\mathrm{O}_{2}$ content. 
For induction and maintenance of anesthesia, the following drugs were administered:

Ketamine (Ketavet ${ }^{\mathrm{TM}}$, Parke-Davis, Berlin, Germany)

Midazolam (Midazolam ${ }^{\mathrm{TM}}$, Ratiopharm, Ulm, Germany)

Propofol (Propofol ${ }^{\mathrm{TM}}$, Braun, Melsungen, Germany)

Fentanyl (Fentanyl ${ }^{\mathrm{TM}}$, Janssen, Neuss, Germany)

Electrolyte solution (Tutofusin ${ }^{\mathrm{TM}}$, Baxter, Unterschleissheim, Germany)
Rocuronium bromide (Esmeron ${ }^{\mathrm{TM}}$, Essex Pharma, Oberschleissheim, Germany)

Sugammadex Bridion $^{\mathrm{TM}}$, Essex Pharma, Oberschleissheim, Germany)

The hemodilution protocol was performed with HES 130/0.4, Voluven $^{\mathrm{TM}}$, Fresenius Kabi, Bad Homburg, Germany.

\section{References}

1 Messmer KF: Acceptable hematocrit levels in surgical patients. World J Surg 1987;11:4146.

2 Habler OP, Messmer KF: The physiology of oxygen transport. Transfus Sci 1997;18:425435 .

3 Madjdpour C, Spahn DR, Weiskopf RB: Anemia and perioperative red blood cell transfusion: a matter of tolerance. Crit Care Med 2006;34:S102-S108.

4 Cain SM: Oxygen delivery and uptake in dogs during anemic and hypoxic hypoxia. J Appl Physiol 1977;42:228-234.

5 Schumacker PT, Cain SM: The concept of a critical oxygen delivery. Intensive Care Med 1987; 13:223-229.

6 Pape A, Habler O: Alternatives to allogeneic blood transfusions. Best Pract Res Clin Anaesthesiol 2007;21:221-239.

7 Marik PE, Kaufman D: The effects of neuromuscular paralysis on systemic and splanchnic oxygen utilization in mechanically ventilated patients. Chest 1996;109:1038-1042.

8 Vernon DD, Witte MK: Effect of neuromuscular blockade on oxygen consumption and energy expenditure in sedated, mechanically ventilated children. Crit Care Med 2000;28: 1569-1571.

9 Herweling A, Latorre F, Herwig A, Horstick G, Kempski O, Gervais HW: The hemodynamic effects of ephedrine on the onset time of rocuronium in pigs. Anesth Analg 2004; 99:1703-1707.

10 Meier JM, Wölkhammer S, Habler OP: The DeltaCrit System (DCS): a computer program for standardized bedside detection of critical oxygen delivery using the Deltatrac II metabolic monitor. Comput Biol Med 2003;33:395-405.

11 Haller M, Akbulut C, Brechtelsbauer H, Fett W, Briegel J, Finsterer U, Peter K: Determination of plasma volume with indocyanine green in man. Life Sci 1993;53:1597-1604.

12 Meier JM, Kemming GI, Kisch-Wedel H, Wolkhammer S, Habler OP: Hyperoxic ventilation reduces 6-hour mortality at the critical hemoglobin concentration. Anesthesiology 2004;100:70-76.
13 Meier J, Pape A, Loniewska D, Lauscher P, Kertscho H, Zwissler B, Habler O: Norepinephrine increases tolerance to acute anemia. Crit Care Med 2007;35:1484-1492.

14 Meier JM, Pape A, Lauscher P, Zwissler B, Habler OP: Hyperoxia in lethal methemoglobinemia - effects on $\mathrm{O}_{2}$ transport, tissue oxygenation and survival in pigs. Crit Care Med 2005;33:1582-1588.

15 Pape A, Kertscho H, Meier J, Horn O, Laout M, Steche M, Lossen M, Theisen A, Zwissler B, Habler O: Improved short-term survival with polyethylene glycol modified hemoglobin liposomes in critical normovolemic anemia. Intensive Care Med 2008;34:1534-1543.

16 Perez-de-Sa V, Roscher R, Cunha-Goncalves D, Larsson A, Werner O: Mild hypothermia has minimal effects on the tolerance to severe progressive normovolemic anemia in swine. Anesthesiology 2002;97:1189-1197.

17 Pape A, Meier J, Kertscho H, Steche M, Laout M, Schwerdel F, Wedel M, Zwissler B, Habler OP: Hyperoxic ventilation increases the tolerance of acute normovolemic anemia in anesthetized pigs. Crit Care Med 2006;34: 1475-1482.

18 Kemming GI, Meisner FG, Kleen MS, Meier JM, Tillmanns JH, Hutter JW, Wojtczyk CJ, Packert KB, Bottino DA, Habler OP: Hyperoxic ventilation at the critical haematocrit. Resuscitation 2003;56:289-297.

19 Meisner FG, Kemming GI, Habler OP, Kleen MS, Tillmanns JH, Hutter JW, Bottino DA Thein E, Meier JM, Wojtczyk CJ, Pape A, Messmer KF: Diaspirin crosslinked hemoglobin enables extreme hemodilution beyond the critical hematocrit. Crit Care Med 2001;29:829-838.

20 Habler OP, Kleen MS, Hutter JW, Podtschaske AH, Tiede M, Kemming GI, Welte MV, Corso CO, Batra S, Keipert PE, Faithfull NS, Messmer KF: Hemodilution and intravenous perflubron emulsion as an alternative to blood transfusion: effects on tissue oxygenation during profound hemodilution in anesthetized dogs. Transfusion 1998;38: 145-155.

21 van der Linden P, De Hert S, Mathieu N, Degroote $\mathrm{F}$, Schmartz $\mathrm{D}$, Zhang $\mathrm{H}$, Vincent JL: Tolerance to acute isovolemic hemodilution. Effect of anesthetic depth. Anesthesiology 2003;99:97-104.
22 Ickx BE, Rigolet M, van der Linden P: Cardiovascular and metabolic response to acute normovolemic anemia. Effects of anesthesia. Anesthesiology 2000;93:1011-1016.

23 Levy PS, Kim SJ, Eckel PK, Chavez R, Ismail EF, Gould SA, Ramez SM, Crystal GJ: Limit to cardiac compensation during acute isovolemic hemodilution: influence of coronary stenosis. Am J Physiol 1993;265:H340H349.

24 Kim J, Shen W, Gallagher D, Jones A Jr, Wang Z, Wang J, Heshka S, Heymsfield SB: Totalbody skeletal muscle mass: estimation by dual-energy X-ray absorptiometry in children and adolescents. Am J Clin Nutr 2006;84: 1014-1020.

25 Eisenberg E, Hill TL: Muscle contraction and free energy transduction in biological systems. Science 1985;227:999-1006.

26 Naguib M: Sugammadex: another milestone in clinical neuromuscular pharmacology. Anesth Analg 2007;104:575-581.

27 Kampe S, Krombach JW, Diefenbach C: Muscle relaxants. Best Pract Res Clin Anaesthesiol 2003;17:137-146.

28 Muldoon SM, Theye RA: The effects of succinylcholine and d-tubocurarine on oxygen consumption. Anesthesiology 1969;31:437442 .

29 McCall M, Jeejeebhoy K, Pencharz P, Moulton R: Effect of neuromuscular blockade on energy expenditure in patients with severe head injury. JPEN J Parenter Enteral Nutr 2003;27:27-35

30 Barton RG, Craft WB, Mone MC, Saffle JR: Chemical paralysis reduces energy expenditure in patients with burns and severe respiratory failure treated with mechanical ventilation. J Burn Care Rehabil 1997;18:461-468.

31 Russell WC, Greer R, Harper NJ: The effect of neuromuscular blockade on oxygen supply, consumption, and total chest compliance in patients with high oxygen requirements undergoing mechanical ventilation. Anaesth Intensive Care 2002;30:192-197.

32 Werlhof V, Sessler DI: Pancuronium does not decrease oxygen consumption during hypothermic or normothermic cardiopulmonary bypass. Anesth Analg 1995;81:465468 
33 Richardson RS: Oxygen transport and utilization: an integration of the muscle systems. Adv Physiol Educ 2003;27:183-191.

34 Pittman RN: Oxygen supply to contracting skeletal muscle at the microcirculatory level: diffusion vs convection. Acta Physiol Scand 2000;168:593-602.

35 Koskolou MD, Roach RC, Calbet JA, Radegran G, Saltin B: Cardiovascular responses to dynamic exercise with acute anemia in humans. Am J Physiol 1997;273:H1787-H1793.
36 Holt JP, Rhode EA, Kines H: Ventricular volumes and body weight in mammals. Am J Physiol 1968;215:704-715.

37 Fontana JL, Welborn L, Mongan PD, Sturm P, Martin G, Bunger R: Oxygen consumption and cardiovascular function in children during profound intraoperative normovolemic hemodilution. Anesth Analg 1995;80:219 225.

38 van Woerkens EC, Trouwborst A, van Lanschot JJ: Profound hemodilution: what is the critical level of hemodilution at which oxygen delivery-dependent oxygen consumption starts in an anesthetized human? Anesth Analg 1992;75:818-821.
39 Zollinger A, Hager P, Singer T, Friedl HP, Pasch T, Spahn DR: Extreme hemodilution due to massive blood loss in tumor surgery. Anesthesiology 1997;87:985-987.

40 van der Linden P, Schmartz D, De Groote F, Mathieu N, Willaert P, Rausin I, Vincent JL: Critical haemoglobin concentration in anaesthetized dogs: comparison of two plasma substitutes. Br J Anaesth 1998;81:556-562. 